\title{
Oiva työkalupakki nuorille klassikoiden selättämiseen
}

Maria Laakso: Taltuta klassikko! Kuvittanut Johanna Rojola. Helsinki: Tammi, 2019, 216 s.

Iso-Britanniassa ja Yhdysvalloissa julkaistaan jo taaperoikäisille johdatuksia maailmankirjallisuuden klassikoihin. Ilmiö ei ole enää Suomessakaan aivan tuntematon: kartonkisivuinen Anne Vaskon Jukolan seitsemän poikaa: Luvunlaskua Aleksis Kiven tapaan (Tammi 2016) johdattaa perheen pienimmätkin pätevästi Aleksis Kiven kieleen ja tuotannon kivijalkaan. Mauri Kunnas puolestaan on luotsannut jo useamman kotimaisen ja maailmankirjallisuuden klassikon pariin koiramaisissa kuvakirjamukaelmissaan.

Tamperelainen kirjallisuudentutkija Maria Laakso on tarttunut haasteeseen lisätä myös teini-ikäisten klassikkotietämystä. Taltuta klassikko! ottaa samalla kantaa aikuisten lietsomaan, nuorten vähentyneeseen vapaa-ajan lukemiseen liittyvään huolipuheeseen. Melkein voisi luulla, että kyse olisi äidinkielenopettajien kirjallisuuden ammattilaiselle antamasta tilaustyöstä. Tietokirjan alkuidea juontaa kuitenkin jo reilun kolmen vuoden taakse: Laakso osallistui Tammen Ihan totta! -tietokirjakilpailuun, jossa etsittiin uusia tietokirja-aiheita lapsille ja nuorille. Laakson idea sai toisen palkinnon nuorille suunnattujen tietokirjojen sarjassa.

Taltuta klassikko! on omiaan yläkoulua päättävälle ja lukioikäiselle nuorelle, joka kamppailee äidinkielen ja kirjallisuuden tunnilla pakkoluetettavien kotimaisten klassikkojen äärellä. Se tulee varmasti kulumaan kirjallisuudenopiskelijoidenkin käsissä, ehkäpä jo pääsykoekirjana tai johdantokurssien osana. Teoksen äärellä viihtyy myös hieman varttuneempi kirjallisuusentusiasti, joka saattaa Laakson freesin analysoinnin ansiosta innostua entuudestaan tutuista klassikoista aivan uudella tavalla.

Laakson teos ei kuitenkaan ole mikään oikotie onneen, vaikka hän puhuu itsekin kursailematta klassikkobluffista. Klassikoiden taltutukseen tarvitaan nimittäin ennen muuta reipasta retkimieltä ja hyviä istumalihaksia. Laakson luupin alla on kahdeksan keskeistä kotimaista klassikkoa, jotka esitellään kronologisessa järjestyksessä. Taltutus aloitetaan Kalevalasta, josta siirrytään Kiven Seitsemään veljekseen ja Minna Canthin Työmiehen vaimoon. 1900-luvulta käsittelyyn tulevat Edith Södergranin runous, L. Onervan Mirdja, Aino Kallaksen Sudenmorsian sekä Mika Waltarin Sinuhe egyptiläinen ja Väinö Linnan Tuntematon sotilas. Teokset käsitellään peräkkäin liki samalla metodilla, mutta silti sopivasti varioiden. 
Laakso ei aliarvioi oletettuja nuoria lukijoitaan ja puhuu siis kursailematta myös kaanonista ja sen muodostumisesta muistuttaen heti perään kerkeästi, että tämäkin teos "sivuuttaa monet hyvät kirjat ja nostaa framille vain tietyt". Tekijöiden elämäkerrallisia tietoja tuodaan harkittuina nostoina, teokset kontekstoidaan aikaansa ja kirjalliseen keskusteluun, mutta samalla klassikoita tulkitaan siekailematta myös nykypäivän termien ja assosiaatioiden kautta. Juoni ja henkilöhahmot esitellään ja muutamien osalta tuodaan esille niistä tehtyjä adaptaatioita. Vaivattoman tuntuisesti Laakso ujuttaa tekstiinsä myös kirjallisuudentutkimuksen avainkäsitteitä ja liittää teoksia myös perustellusti osaksi tämänhetkistä yhteiskunnallista keskustelua.

Klassikoista on valittu järkiään hyviä ja riittävän lyhyitä katkelmia analyysin tueksi. Lukijalle ei missään vaiheessa tule tunnetta, että häntä yritetään vasiten sivistää. Suomalaisen kirjallisuudenhistorian ja klassikkojen juonien nykykielistämisessä Laakso tekee todellisen kulttuuriteon. Hän käyttää nykynuorison rentoa ja värittynyttä puhekieltä kautta kirjan, yhtälaisesti teosten juonitiivistelmissä, kirjallisuudentutkimuksen eritystermien selityksessä kuin kirjallisuushistorian nasevissa koonneissakin.

Teoksen tärkein kirjallisuuspedagoginen ansio löytyy kuitenkin toisaalta: Laakso osoittaa nimittäin rivien välissä nasevasti sen, kuinka tärkein heräte lukemisen tajuntaa räjäyttävästä voimasta tulee toteen näytetyksi vain ja ainoastaan silloin, kun nuori saa itse, omilla ehdoillaan, oivaltaa lukemansa kirjallisuuden vivahteet ja ylivertaisuuden. Ja tähän klassikoiden selättämiseen Laakso antaakin nykynuorille juuri sopivan kokoisen työkalupakin. Hänen luentansa riisuu klassikoista kaiken pönötyksen ja tuo kotimaisten klassikkojen opetukseen ja tulkintaan kipeästi kaivattua anarkiaa. Verbaalisesta tykityksestä ja kieli poskessa -tyylisestä huumorista huolimatta teoksen pohjalla näkyy ja kuuluu rautainen asiantuntemus ja kunnioitus käsiteltyjä teoksia kohtaan.

Parhaillaan Maria Laaksolla on työn alla jatko-osa maailmankirjallisuuden klassikoista.

Päivi Heikkilä-Halttunen 